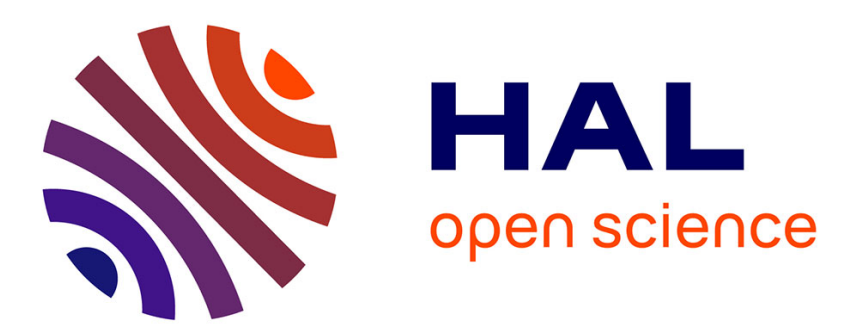

\title{
Influence of temperature and applied potential on the permeability of polyphenol films prepared on vitreous carbon in acid and alkaline media
}

Noureddine Belhadj Tahar, André Savall

\section{- To cite this version:}

Noureddine Belhadj Tahar, André Savall. Influence of temperature and applied potential on the permeability of polyphenol films prepared on vitreous carbon in acid and alkaline media. Journal of Applied Electrochemistry, 2013, vol. 43 ( $\mathrm{n}^{\circ} 6$ ), pp. 595-604. 10.1007/s10800-013-0540-7 . hal02354573

\section{HAL Id: hal-02354573 \\ https://hal.science/hal-02354573}

Submitted on 7 Nov 2019

HAL is a multi-disciplinary open access archive for the deposit and dissemination of scientific research documents, whether they are published or not. The documents may come from teaching and research institutions in France or abroad, or from public or private research centers.
L'archive ouverte pluridisciplinaire HAL, est destinée au dépôt et à la diffusion de documents scientifiques de niveau recherche, publiés ou non, émanant des établissements d'enseignement et de recherche français ou étrangers, des laboratoires publics ou privés. 


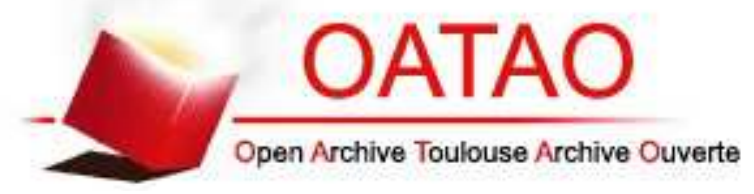

\section{Open Archive TOULOUSE Archive Ouverte (OATAO)}

OATAO is an open access repository that collects the work of Toulouse researchers and makes it freely available over the web where possible.

This is an author-deposited version published in : http://oatao.univ-toulouse.fr/ Eprints ID : 9951

To link to this article : DOI:10.1007/s10800-013-0540-7

URL : http://dx.doi.org/10.1007/s10800-013-0540-7

To cite this version : Belhadj Tahar, Noureddine and Savall, André. Influence of temperature and applied potential on the permeability of polyphenol films prepared on vitreous carbon in acid and alkaline media. (2013) Journal of Applied Electrochemistry, vol. 43 ( ${ }^{\circ} 6$ ). pp. 595604. ISSN 0021-891X

Any correspondance concerning this service should be sent to the repository administrator: staff-oatao@ listes-diff.inp-toulouse.fr 


\title{
Influence of temperature and applied potential on the permeability of polyphenol films prepared on vitreous carbon in acid and alkaline media
}

\author{
Noureddine Belhadj Tahar · André Savall
}

\begin{abstract}
The electrochemical polymerization of phenol is known to rapidly produce a thin insulating film at the anode surface. This film generally blocks further polymerization. The objective of this study is to show that, depending on the operating conditions, polymeric films resulting from phenol oxidation present different properties and that certain films can be so porous that they allow the oxidation of phenol to continue. The deposition of polyphenol films with improved permeability could be attractive in the removal of phenol from polluted solutions. Polyphenol films were prepared in aqueous solution on a vitreous carbon anode either by cyclic voltammetry or by electro-oxidation at constant potential. The apparent permeability $P(\%)$ of the films prepared by these techniques was evaluated by monitoring changes in the electrode response towards phenol and potassium ferricyanide at 25 and $85{ }^{\circ} \mathrm{C}$ and as a function of the potential applied during electropolymerization performed either in acidic $\left(1 \mathrm{~mol} \mathrm{~L}^{-1}\right.$ $\left.\mathrm{H}_{2} \mathrm{SO}_{4}\right)$ or in alkaline $\left(1 \mathrm{~mol} \mathrm{~L}^{-1} \mathrm{NaOH}\right)$ aqueous solution. It was shown that: (1) the polyphenol film electrosynthesized in alkaline medium was more permeable than that prepared in acidic medium, (2) the apparent permeability was higher when the polyphenol film was electrosynthesized with simultaneous oxygen evolution and (3) the use of a high temperature in the polyphenol film preparation, especially in
\end{abstract}

\section{N. Belhadj Tahar}

Institut Supérieur des Sciences Appliquées et Technologie de Mahdia, Université de Monastir, Monastir, Tunisia

e-mail: nour.belhadj@fsm.rnu.tn

\section{A. Savall (ه)}

Laboratoire de Génie Chimique, CNRS, Université Paul Sabatier, 118, Route de Narbonne, 31062 Toulouse cedex, France

e-mail: savall@chimie.ups-tlse.fr the presence of a concomitant oxygen evolution, significantly enhanced its apparent permeability $(P \geq 100 \%)$. These results are interpreted in terms of a mixed-transport mechanism involving both pore and membrane diffusion. The effect of the permeability of the polymeric film on the removal of phenol from aqueous solution by electropolymerization is discussed.

Keywords Phenol · Vitreous carbon ·

Electropolymerization · Permeability $\cdot$ Electrochemical depollution

\section{Introduction}

Electrochemical oxidation of phenolic compounds is well known to cause the inactivation of various electrode materials by the deposition of an adherent, compact, insulating film formed by polymerization [1-6]. Thus, polymeric films formed during the oxidation of phenolic compounds have been generally regarded as a cumbersome problem in electrochemical wastewater treatment processes. However, electropolymerization of phenol involving less than two electrons per molecule [7, 8] could be considered as a means for its removal from water as an alternative to mineralization approaches. Attempts were carried out in this objective by using electrodes of largespecific area andlor weak concentrations of phenol to limit fouling [9-12]. Other experiments were performed to avoid the formation of a passive layer by using either a surfactant [13] dispersed in the electrolyte or a working electrode made of a conductive polymer like polyaniline [14].

Recently we studied the removal of phenol from aqueous solution by anodic polymerization [15-19]. Galvanostatic electrolyses conducted on a $\mathrm{Ta} / \beta-\mathrm{PbO}_{2}$ anode at high 
current density $\left(200 \mathrm{~mA} \mathrm{~cm}^{-2}\right)$ and high temperature $\left(86{ }^{\circ} \mathrm{C}\right)$ showed that $39 \%$ of the starting phenol can be removed as polymer dispersed in the anolyte $[15,16]$. The use of high anodic current density avoided anode fouling but unfortunately favoured both oxidation of the polymeric film and oxygen evolution leading to current yields of around $20 \%$ [16]. We have also investigated the electrochemical behavior of phenol on a vitreous carbon electrode by cyclic voltammetry and chronoamperometry in acid [17] and basic [18, 19] aqueous solutions at different temperatures in the range $25-85^{\circ} \mathrm{C}$. Cyclic voltammetry performed in the potential region of water stability has shown that: (1) phenol oxidation is controlled by adsorption in acid solution and diffusion in basic solution, (2) the vitreous carbon electrode was effectively deactivated vis-àvis phenol oxidation as early as the second potential scan whatever the temperature or $\mathrm{pH}$ used and (3) electrode activity was progressively restored over successive potential scans in basic medium only at temperatures of over $60{ }^{\circ} \mathrm{C}$ while no such reactivation was observed in acid medium even at $85{ }^{\circ} \mathrm{C}$. On the other hand, chronoamperometric measurements conducted in basic medium at a potential in the region of water stability have shown that, at temperatures higher than $60{ }^{\circ} \mathrm{C}$, the resulting polymeric film did not deactivate the electrode [18]. However, the electrochemical activity was effectively blocked when the electrode was polarized in acid medium at a potential in the region of water stability even at $85^{\circ} \mathrm{C}$. In contrast, electrode deactivation was significantly reduced or prevented during anodic polarization at a constant potential in the water discharge region whatever the temperature used in the range $25-85^{\circ} \mathrm{C}$ [17].

Focusing our interest in electropolymerization as a possible technique to remove phenol from polluted water we undertook here to optimize operating conditions both to allow electropolymerization to proceed as long as a current is supplied to the electrode and to avoid the resulting electrode fouling. Therefore, the polymeric film must have the highest permeability for phenol molecules. In this new step of our research we present detailed results on the measurement of the apparent permeability of the polymeric film towards phenol and ferricyanide ion as a function of experimental parameters such as temperature and applied potential used in the electropolymerization of phenol. These polyphenol films were deposited either by cyclic voltammetry or by electro-oxidation under controlled potential. Electropolymerization of phenol occurs according to two different mechanisms depending on whether the phenol is in its neutral molecular or phenate ion form [16]; the polymeric films were thus prepared for two typical values of the $\mathrm{pH}$ corresponding to $1 \mathrm{~mol} \mathrm{~L}^{-1} \mathrm{H}_{2} \mathrm{SO}_{4}$ and $1 \mathrm{~mol} \mathrm{~L}{ }^{-1} \mathrm{NaOH}$.

\section{Experimental details}

2.1 Instrumentation, cell, electrodes

Cyclic voltammetry and potentiostatic electrolysis were carried out in a conventional three-electrode cell $(200 \mathrm{~mL})$ using a computer-controlled Eco Chemie Autolab Model 30 (Utrecht, The Netherlands). The working electrode was made of a vitreous carbon disk with a geometric area of $0.0707 \mathrm{~cm}^{2}$. The counter-electrode was a platinum spiral. The reference electrode $\left(\mathrm{Hg} / \mathrm{Hg}_{2} \mathrm{Cl}_{2} / \mathrm{Cl}^{-}\right.$(sat.)) situated outside the cell was inserted into a long Luggin capillary, filled with either $1 \mathrm{~mol} \mathrm{~L}^{-1} \mathrm{NaOH}$ or $1 \mathrm{~mol} \mathrm{~L}^{-1} \mathrm{H}_{2} \mathrm{SO}_{4}$, and whose finely drawn-out point was placed close to the working electrode. Before each experiment, the working electrode was polished to a mirror finish with $1 \mu \mathrm{m}$ alumina slurry on polishing sheet (3 M 262X Imperial Lapping Film) and subsequently washed with distilled water. Regeneration of the electrode surface state by polishing was checked by comparing the cyclic voltammetry response of the polished electrode to that of a bare vitreous carbon electrode in aqueous $10 \mathrm{mmol} \mathrm{L}^{-1}$ potassium ferricyanide solutions containing either $1 \mathrm{~mol} \mathrm{~L}^{-1} \mathrm{NaOH}$ or $1 \mathrm{~mol} \mathrm{~L}^{-1} \mathrm{H}_{2} \mathrm{SO}_{4}$. Each permeation experiment was conducted on a newly modified electrode freshly prepared; the modified electrode was immediately (1) removed from the phenol solution (2) washed with distilled water and (3) subjected to permeation measurement. So, we can exclude and at worst ignore the polyphenol film dissolution by the action of the hydroxide ions during permeation measurement.

\subsection{Data analysis}

The transport of a reactive species from the solution to the electrode surface through a polymer coating is considered to be a complex process [20] involving diffusion of the solute in the polymer and in its pores in addition to solute partition (see Sect. 3.1.2). Facing this complexity it is convenient to characterize the polymeric film by its apparent permeability $P(\%)$ calculated from easily accessible experimental data. The apparent permeability of the film, expressed as a percentage, was calculated from the following expression [20-22]:

$P(\%)=\frac{I_{\text {film }}}{I_{\text {bare }}} \times 100$

where $I_{\text {film }}$ and $I_{\text {bare }}$ are the voltammetric peak currents recorded at the film-coated electrode and that measured at the bare electrode during the 1 st scan on a freshly prepared electrode. The apparent permeability for ferricyanide ions was, unless otherwise specified, assessed by subjecting the bare and polymer-coated vitreous carbon electrodes to 
cycling at $500 \mathrm{mV} \mathrm{s}^{-1}$ in $10 \mathrm{mmol} \mathrm{L}^{-1}$ potassium ferricyanide $+1 \mathrm{~mol} \mathrm{~L}^{-1} \mathrm{NaOH}$ or $\mathrm{H}_{2} \mathrm{SO}_{4}$ at $25^{\circ} \mathrm{C}$ whatever the temperature used for the polyphenol film preparation ( 25 or $85^{\circ} \mathrm{C}$ ). The measurement of $P(\%)$ was based on the measure of the cathodic peak current. Permeation measurements for phenol were conducted at $100 \mathrm{mV} \mathrm{s}^{-1}$ in the same solution and at the same temperature used for the polyphenol film preparation. On the other hand, the experimental precision in the measurements of the peak current of phenol oxidation and ferricyanide ion reduction performed on both bare and polyphenol-coated vitreous carbon electrodes was estimated to be around $5 \%$; thus, the precision in the apparent permeability was evaluated to be around $10 \%$.

\section{Results and discussion}

3.1 Oxidation of phenol in $1 \mathrm{~mol} \mathrm{~L}^{-1} \mathrm{NaOH}$ aqueous solution

\subsubsection{Cyclic voltammetry}

Successive cyclic voltammograms were recorded between 25 and $750 \mathrm{mV}$ on a vitreous carbon electrode for phenol $5 \mathrm{mmol} \mathrm{L}^{-1}$ in $1 \mathrm{~mol} \mathrm{~L}^{-1} \mathrm{NaOH}$ aqueous solution at 25 and $85^{\circ} \mathrm{C}$ (Fig. 1). The first cycle recorded at $25{ }^{\circ} \mathrm{C}$ (Fig. 1a) shows an irreversible anodic peak at $483 \mathrm{mV}$ which corresponds to the oxidation of phenol; this oxidation peak disappeared during the second scan. This rapid and drastic drop in the current intensity results from the deposition of a polymer film which blocks the vitreous carbon surface. The presence of a brown polymeric film was confirmed by visual inspection of the electrode surface; even after the first scan the electrode lost its mirror finish obtained by polishing just before each electrochemical experiment. This is specific of the oxidation of most phenolic compounds [10, 11, 23-25]. It is obvious that the polymeric film formed under these conditions is a material that is both not conducting for electrons and non-permeable to phenol molecules. For the first cycle, the increase in temperature from 25 to $85{ }^{\circ} \mathrm{C}$ induced an increase of the peak current from 90 to $256 \mu \mathrm{A}$ and a shift of the peak potential from 483 to $370 \mathrm{mV}$ (Fig. 1b). This may be explained by an increase of the diffusion coefficient of phenol with temperature leading to a higher oxidation current. A broad but not intense wave situated between 260 and $460 \mathrm{mV}$ corresponding to phenol oxidation was observed during the second cycle; then, the height of this wave increased progressively upon continuous cycling and, after the sixth cycle, became higher than the peak of the 1 st scan.
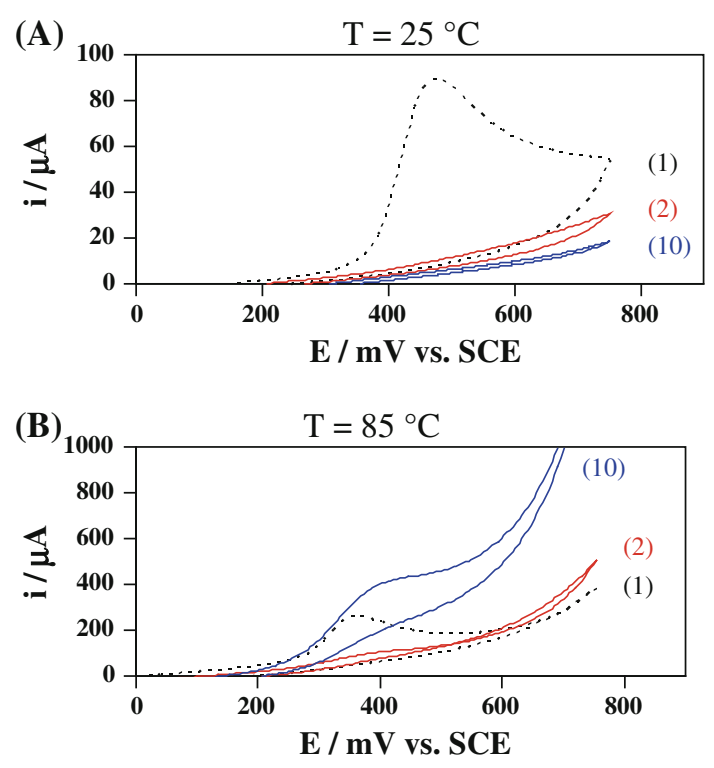

Fig. 1 Cyclic voltammograms recorded on a vitreous carbon electrode for $5 \mathrm{mmol} \mathrm{L}^{-1}$ phenol in $1 \mathrm{~mol} \mathrm{~L}^{-1} \mathrm{NaOH}$ aqueous solution at $25^{\circ} \mathrm{C}$ (a) and $85{ }^{\circ} \mathrm{C}$ (b). Scan rate: $100 \mathrm{mV} \mathrm{s}^{-1}$. (1) first cycle, (2) second cycle, and (10) tenth cycle

Figure 2 shows polarization curves recorded for the vitreous carbon electrode in $1 \mathrm{~mol} \mathrm{~L}^{-1} \mathrm{NaOH}$ aqueous solution at $85{ }^{\circ} \mathrm{C}$ (curve a) and $25^{\circ} \mathrm{C}$ (curve b). Comparing cyclic voltammograms and Fig. 2 shows that oxidation of phenol in alkaline solution occurs by direct electron transfer in the potential region of water stability both at 25 and $85{ }^{\circ} \mathrm{C}$. Accordingly, these conditions favor the development of a polymeric film which is adherent, uniform and compact, leading to electrode deactivation. On the other hand, cyclic voltammograms (first cycles) recorded between 250 and $1,250 \mathrm{mV}$ (not shown) in $1 \mathrm{~mol} \mathrm{~L}^{-1}$ $\mathrm{NaOH}$ in the absence and presence of phenol $5 \mathrm{mmol} \mathrm{L}^{-1}$ at $25{ }^{\circ} \mathrm{C}$ revealed that the anodic oxidation of phenol has no influence on the activity of the electrode towards oxygen evolution proving that the polymeric film has a high permeability for water molecules. Therefore, we assume that the progressive restoration of the electrode activity observed at $85{ }^{\circ} \mathrm{C}$ during the successive scans results from the concomitant oxygen evolution occurring underneath the polymeric film that makes it more porous and permeable to phenol molecules. Indeed, repeated potential scans (not shown) between 25 and $600 \mathrm{mV}$ (potentials situated in the region of water stability as shown by curves $a$ and $b$ in Fig. 2) were unable to reactivate the electrode vis-à-vis phenol oxidation even at $85^{\circ} \mathrm{C}$. Likewise, a deep degradation of the polymer via the electrogenerated hydroxyl radicals may not be evoked on its own to induce electrode reactivation since an adherent film covering the electrode surface completely was always observable by the naked eye after each experiment. These results demonstrate that, 
on the time scale of cyclic voltammetry, the temperature does not play a direct role in electrode reactivation; its indirect role probably consists of decreasing the potential at which oxygen evolution begins [shift around $350 \mathrm{mV}$ when temperature increases from 25 to $85^{\circ} \mathrm{C}$ (Fig. 2)], which helps to reactivate the electrode. Previously we showed [19] that in the polymer layer the $\mathrm{pH}$ could become acid under high current density (in Fig. 1b the current reaches $1 \mathrm{~mA}$ at $700 \mathrm{mV}$ ) forming molecular phenol, and its partition could explain that the height of the oxidation wave beyond the sixth scan exceeded that of the 1st scan [19]. Furthermore, it was shown by Kennedy and Cunnane [26, 27] that, at a scale time of a few minutes, pore ensembles are produced from the degradation of poly(3-aminophenol) films by sodium hydroxide solution $\left(0.01-0.1 \mathrm{~mol} \mathrm{~L}^{-1}\right)$. In the same way, one can assume that the polymer film obtained by electro-oxidation of the phenol can be chemically attacked by the alkaline solution, which would lead the forming of pores.

\subsubsection{Evaluation of the apparent permeability} of the polymeric film prepared by cyclic voltammetry

The apparent permeability of the polymeric films was evaluated by monitoring changes in the electrode response of the ferricyanide ion as a redox marker. Polymeric films were electrodeposited, at either 25 or $85^{\circ} \mathrm{C}$, on freshly polished vitreous carbon by cyclic voltammetry between 25 and $750 \mathrm{mV}$ in $1 \mathrm{~mol} \mathrm{~L}^{-1} \mathrm{NaOH}$ aqueous solution containing $5 \mathrm{mmol} \mathrm{L}^{-1}$ of phenol. Figure $3 \mathrm{a}, \mathrm{b}$ shows cyclic voltammograms (first scans) of $10 \mathrm{mmol} \mathrm{L}^{-1} \mathrm{~K}_{3} \mathrm{Fe}(\mathrm{CN})_{6}$ in $1 \mathrm{~mol} \mathrm{~L}{ }^{-1} \mathrm{NaOH}$ at $25^{\circ} \mathrm{C}$; curves (1) were recorded on bare vitreous carbon. Curves 2 and 3 were recorded on polymer coatings formed during, respectively, 1 and 10 scans at $25^{\circ} \mathrm{C}$ (Fig. 3a) and $85^{\circ} \mathrm{C}$ (Fig. 3b). Figure 3a reveals that the reduction peak current in ferricyanide solution was equal to $-190 \mu \mathrm{A}$ (curve 1) at the bare vitreous carbon electrode while no reduction peak was observed on the polymer-coated electrode prepared at $25^{\circ} \mathrm{C}$ (curves 2 and 3 ). On the other hand, Fig. $3 \mathrm{~b}$ shows that the reduction

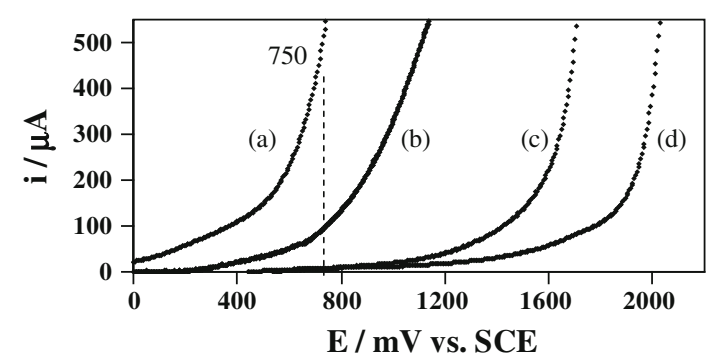

Fig. 2 Linear polarization curves recorded in $1 \mathrm{~mol} \mathrm{~L}^{-1} \mathrm{NaOH}$ at $85^{\circ} \mathrm{C}(a), 1 \mathrm{~mol} \mathrm{~L}-1 \mathrm{NaOH}$ at $25^{\circ} \mathrm{C}(b), 1 \mathrm{~mol} \mathrm{~L}^{-1} \mathrm{H}_{2} \mathrm{SO}_{4}$ at $85^{\circ} \mathrm{C}$ (c) and $1 \mathrm{~mol} \mathrm{~L}^{-1} \mathrm{H}_{2} \mathrm{SO}_{4}$ at $25^{\circ} \mathrm{C}($ d $)$. Scan rate: $100 \mathrm{mV} \mathrm{s}^{-1}$ peak currents in ferricyanide solution were equal to $-50 \mu \mathrm{A}$ (curve 2) and $-267 \mu \mathrm{A}$ (curve 3 ) for polymer-coated electrodes prepared at $85^{\circ} \mathrm{C}$. This confirms that the electrode reactivation results from an increase in the permeability of the polymeric film due to the subjacent concomitant oxygen evolution. Furthermore, cyclic voltammograms of potassium ferricyanide shown in Fig. 3b were quite different in that an irreversible redox system was found at the bare vitreous carbon electrode (curve 1) whereas a quasi-reversible one was found at the polymer-coated electrode (curves 2 and 3 ).

The polymeric film has been modeled as a transport barrier that impedes diffusion of the permeant to the electrode; the two principal transport mechanisms involve diffusion (i) through the bulk of the film and (ii) inside the pores within the film $[20,28]$. In the pore mechanism, the current flux for the electrochemical reaction would be forced through the small pore acting effectively as an ultramicroelectrode [26] producing changes in the reversibility of the electrochemical reaction [29]. One can thus assume that for the ferricyanide anion a mechanism involving pore diffusion progressively becomes the dominant transport mechanism as the number of scans increases in films prepared at $85^{\circ} \mathrm{C}$. On the other hand, the fact that polyphenol films prepared at $25{ }^{\circ} \mathrm{C}$ effectively excluded the ferricyanide ion (Fig. 3a, curves 2 and 3) shows that (1) these films were free of pores with large radii in comparison to that of the permeant and that (2) the transport of the
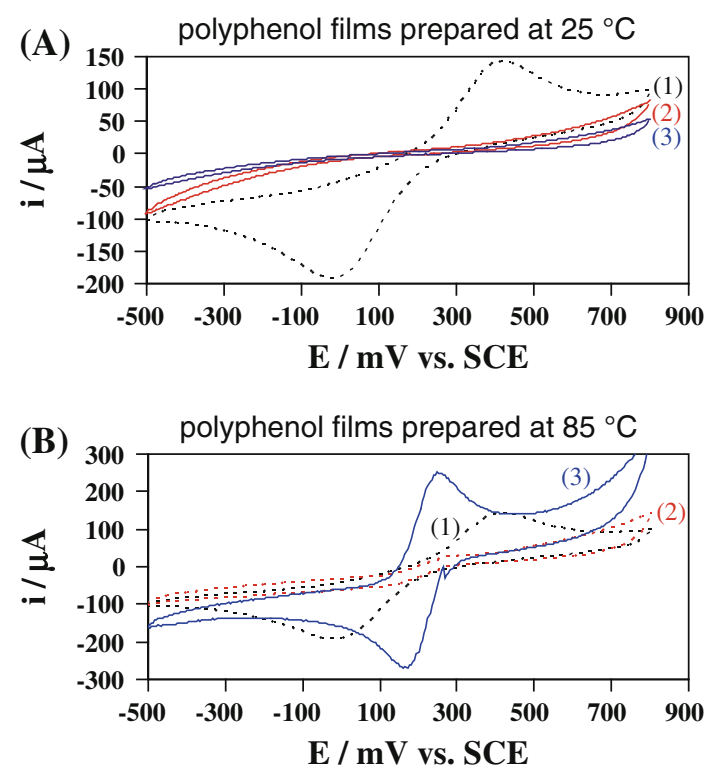

Fig. 3 Cyclic voltammograms (first cycles) recorded at $25^{\circ} \mathrm{C}$ on bare (curve 1) and polyphenol film-coated (curves 2 and 3) vitreous carbon electrodes in $1 \mathrm{~mol} \mathrm{~L}^{-1} \mathrm{NaOH}$ aqueous solution containing $10 \mathrm{mmol} \mathrm{L}^{-1}$ potassium ferricyanide; scan rate: $500 \mathrm{mV} \mathrm{s}^{-1}$. The polyphenol films were prepared by cyclic voltammetry during 1 scan (curves 2) and 10 scans (curves 3) between 25 and $750 \mathrm{mV}$ at $100 \mathrm{mV} \mathrm{s}^{-1}$ in $1 \mathrm{~mol} \mathrm{~L}^{-1} \mathrm{NaOH}$ aqueous solution containing $5 \mathrm{mmol} \mathrm{L}{ }^{-1}$ phenol at $25^{\circ} \mathrm{C}\left(\right.$ a) and $85^{\circ} \mathrm{C}(\mathbf{b})$ 
large ferricyanide ion by a membrane diffusion process was, as expected, not possible since this process is sensitive to the molecular size of the permeant [29].

\subsubsection{Evaluation of the apparent permeability of the polymeric film prepared under potentiostatic conditions}

Polymeric films were prepared by constant anodic polarization of the vitreous carbon electrode at various potentials between 400 and 1,500 $\mathrm{mV}$ applied for $10 \mathrm{~min}$ in $1 \mathrm{~mol} \mathrm{~L}^{-1}$ $\mathrm{NaOH}$ aqueous solution containing $5 \mathrm{mmol} \mathrm{L}^{-1}$ of phenol. Each polymer-coated electrode was then rinsed with distilled water. An overview of the cyclic voltammograms presented in Fig. 4 shows that for ferricyanide ion: (1) a more reversible redox system was obtained at polyphenol film-coated electrodes than at the bare electrode, $(2)$ the $\left[\mathrm{Fe}(\mathrm{CN})_{6}\right]^{3-}$ reduction peak potential was independent of the potential applied during polyphenol film preparation at both $25^{\circ} \mathrm{C}$ (Fig. 4a) and $85^{\circ} \mathrm{C}$ (Fig. 4b).

Figure 5a shows that the polyphenol films prepared at $25{ }^{\circ} \mathrm{C}$ affect the electrochemical response of the vitreous carbon electrode for phenate ion in that the peak potential was shifted towards more positive values than those obtained at the bare electrode whatever the potential applied during film preparation. For films prepared at $25{ }^{\circ} \mathrm{C}$, the anodic peak current increased with potential until $800 \mathrm{mV}$ then decreased for potential values superior to $800 \mathrm{mV}$, while for films prepared at $85^{\circ} \mathrm{C}$ the decrease of the peak current started at $700 \mathrm{mV}$. In every case, whatever the potential applied during the preparation of the film the oxidation peak current of phenate ion was higher than that on bare vitreous carbon (Fig. 5b) leading apparent permeability values $P(\%)>100 \%$. In fact, when the film is prepared for increasing values of the potential the $\mathrm{pH}$ of the layer at the contact of the anode can become acid what favors its partial deactivation [19]; however, the release of oxygen favoring the forming of pores prevents a complete deactivation.

Figure 6 shows the relationships between the apparent permeability and the potential applied during the formation of the polymeric film at $25{ }^{\circ} \mathrm{C}$ in $1 \mathrm{~mol} \mathrm{~L}^{-1} \mathrm{NaOH}$. For applied potentials below $600 \mathrm{mV}$ (in the potential region of water stability), the resulting polymeric film had a low permeability for phenate ion while it effectively excluded the ferricyanide ion. Increasing the applied potential up to $800 \mathrm{mV}$ (at the onset of oxygen evolution) resulted in an increase in the permeability of the film for both ferricyanide and phenate ions. For applied potentials above $800 \mathrm{mV}$ (with significant oxygen evolution), $P$ (\%) decreased for phenate ion whereas it increased slightly for ferricyanide ion.

To demonstrate that these high permeability values were real and not caused by the low thickness or low surface coverage of the film due to its dissolution during permeation measurement by chemical reaction with the hydroxide anions $\left([\mathrm{NaOH}]=1 \mathrm{~mol} \mathrm{~L}^{-1}\right)$, the apparent permeability for ferricyanide anion was evaluated in $\mathrm{pH} 7$ sodium phosphate $\left(0.1 \mathrm{~mol} \mathrm{~L}^{-1}\right)$ buffer solution containing $10 \mathrm{mmol} \mathrm{L}{ }^{-1}$ potassium ferricyanide at $25^{\circ} \mathrm{C}$ where we verified that polyphenol films were chemically very stable. The polyphenol film used in permeation measurement was prepared at $25^{\circ} \mathrm{C}$ by anodic polarization at $1,200 \mathrm{mV}$ under more drastic conditions, namely for $30 \mathrm{~min}$ (instead of $10 \mathrm{~min}$ ) and in $1 \mathrm{~mol} \mathrm{~L}^{-1} \mathrm{NaOH}$ aqueous solution containing $10 \mathrm{mmol} \mathrm{L}^{-1}$ (instead of $5 \mathrm{mmol} \mathrm{L}^{-1}$ ) phenol; the apparent permeability for ferricyanide anions, calculated from the cyclic voltammograms presented in Fig. 7, was equal to $75 \%$ a value of the same order than that given in Fig. $6(81 \%)$ obtained with polyphenol film prepared by
Fig. 4 Cyclic voltammograms (first cycles) recorded on bare and polyphenol film-coated vitreous carbon electrodes in $1 \mathrm{~mol} \mathrm{~L}^{-1} \mathrm{NaOH}$ aqueous solution containing $10 \mathrm{mmol} \mathrm{L}^{-1} \mathrm{~K}_{3} \mathrm{Fe}(\mathrm{CN})_{6}$ at $25^{\circ} \mathrm{C}$. Scan rate: $500 \mathrm{mV} \mathrm{s}^{-1}$. The polyphenol films were prepared by anodic polarization at various applied potentials $(400-1,500 \mathrm{mV})$ for $10 \mathrm{~min}$ in $1 \mathrm{~mol} \mathrm{~L}^{-1} \mathrm{NaOH}$ aqueous solution containing $5 \mathrm{mmol} \mathrm{L}{ }^{-1}$ phenol at $25^{\circ} \mathrm{C}$ (a) and $85^{\circ} \mathrm{C}$ (b)

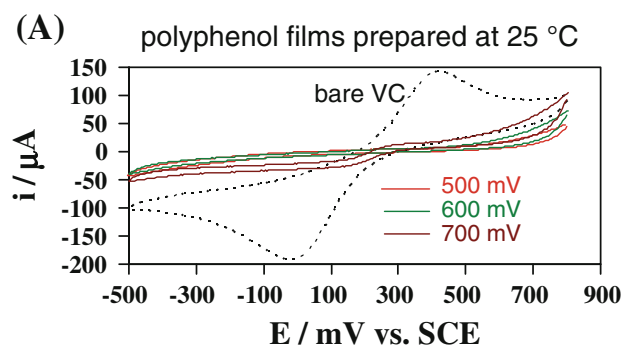

(B)

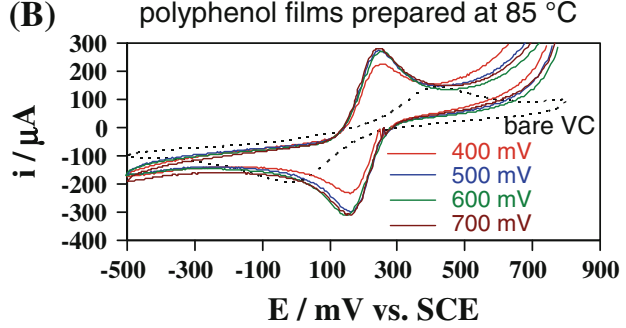

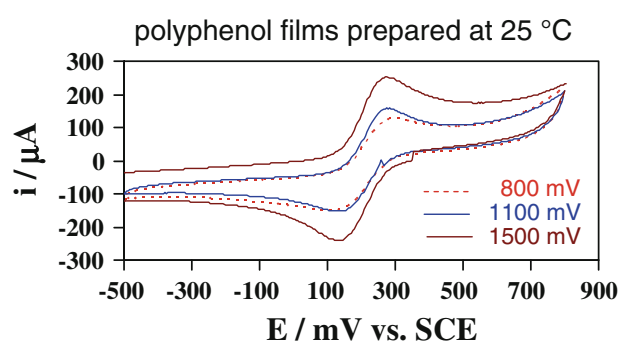

polyphenol films prepared at $85^{\circ} \mathrm{C}$

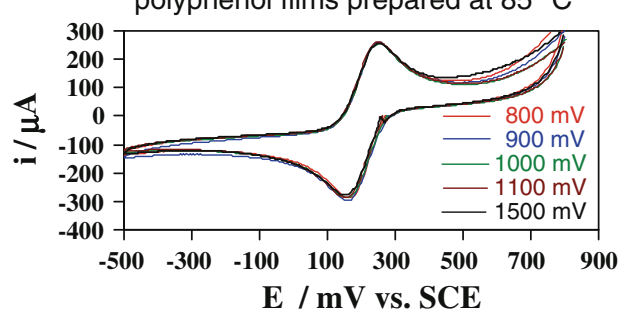


Fig. 5 Cyclic voltammograms (first cycles) recorded on bare and polyphenol film-coated vitreous carbon electrodes in $1 \mathrm{~mol} \mathrm{~L}{ }^{-1} \mathrm{NaOH}$ aqueous solution containing $5 \mathrm{mmol} \mathrm{L}^{-1}$ phenol at $25^{\circ} \mathrm{C}\left(\right.$ a) and $85^{\circ} \mathrm{C}$ (b). Scan rate: $100 \mathrm{mV} \mathrm{s}^{-1}$. The polyphenol films were prepared by anodic polarization at various applied potentials $(400-1,500 \mathrm{mV}$ ) for $10 \mathrm{~min}$ in $1 \mathrm{~mol} \mathrm{~L}^{-1} \mathrm{NaOH}$ aqueous solution containing $5 \mathrm{mmol} \mathrm{L}{ }^{-1}$ phenol at $25^{\circ} \mathrm{C}$ (a) and $85^{\circ} \mathrm{C}$ (b)
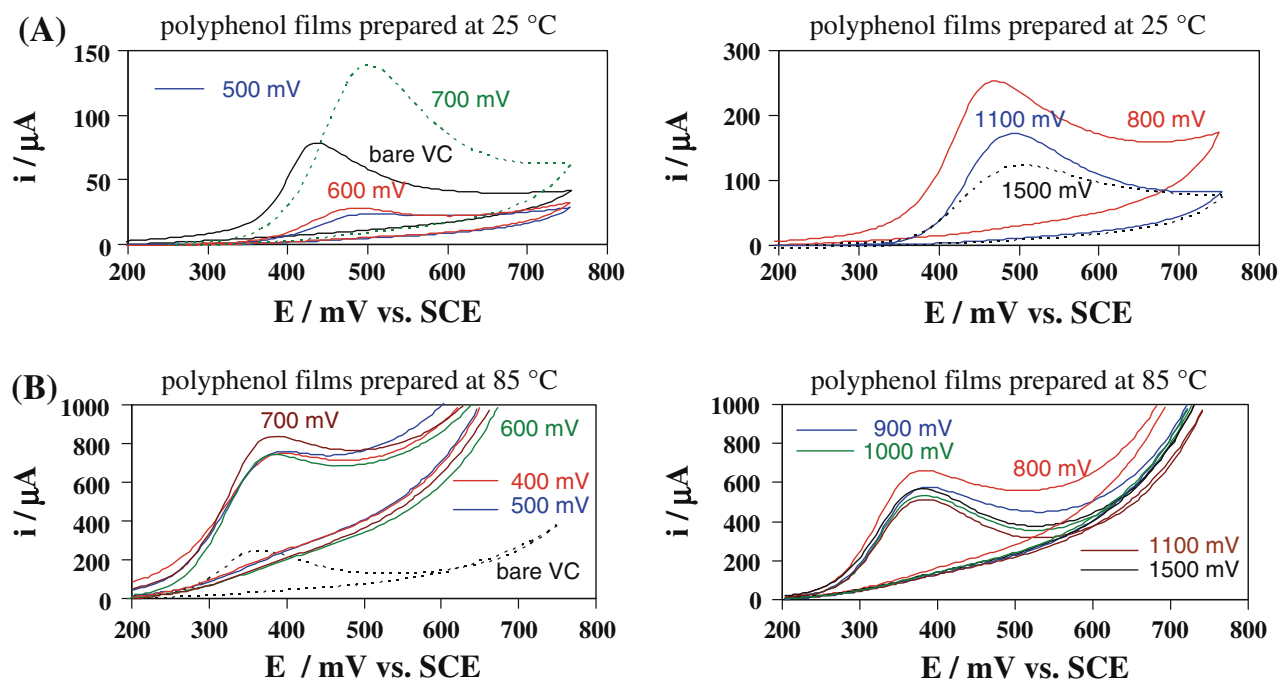

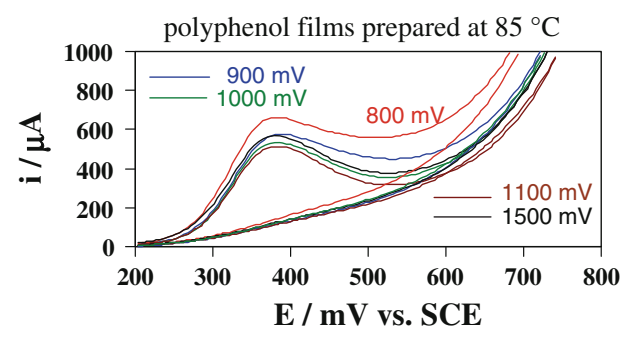

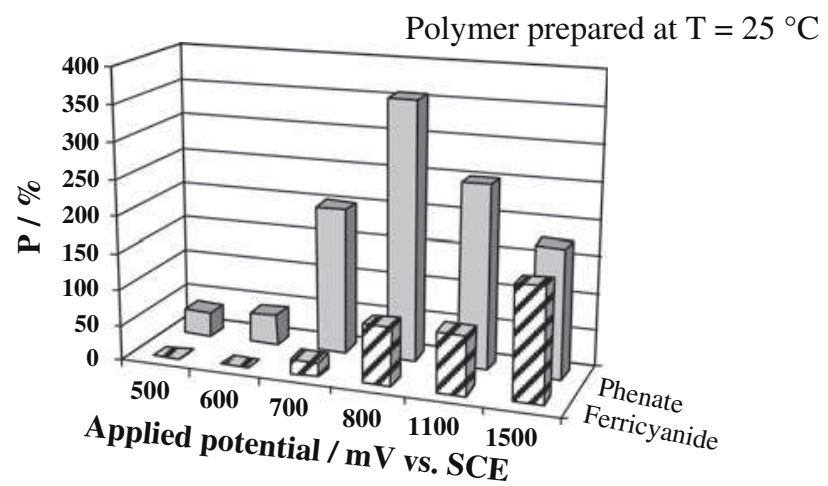

Fig. 6 Relationships between apparent permeability and applied potential. The polymeric film was prepared by anodic polarization at various applied potentials $(500-1,500 \mathrm{mV})$ for $10 \mathrm{~min}$ in $1 \mathrm{~mol} \mathrm{~L}^{-1}$ $\mathrm{NaOH}$ aqueous solution containing $5 \mathrm{mmol} \mathrm{L}{ }^{-1}$ phenol at $25{ }^{\circ} \mathrm{C}$. The permeability values $P(\%)$ of the polymeric film for ferricyanide and phenate ions were, respectively, calculated from cyclic voltammograms depicted in Figs. 4a and 5a

anodic polarization at $1,100 \mathrm{mV}$ for $10 \mathrm{~min}$ in $1 \mathrm{~mol} \mathrm{~L}^{-1}$ $\mathrm{NaOH}$ aqueous solution containing $5 \mathrm{mmol} \mathrm{L}^{-1}$ phenol at $25{ }^{\circ} \mathrm{C}$. This suggests that films prepared in $1 \mathrm{~mol} \mathrm{~L}^{-1}$ $\mathrm{NaOH}$ have a real stability in spite of their high relative permeability.

Figure 8 shows that the polymeric film prepared at $85{ }^{\circ} \mathrm{C}$ in $1 \mathrm{~mol} \mathrm{~L}^{-1} \mathrm{NaOH}$ was permeable for both ferricyanide and phenate ions whatever the applied potential (between 400 and $1,500 \mathrm{mV}$ ). Although the apparent permeability of the film for ferricyanide ion remained independent from the applied potential, that of phenate decreased slightly from 700 to $900 \mathrm{mV}$ without, however, the value falling below $250 \%$. Results presented in Fig. 8 appear to be consistent with the formation within the film of pores wide enough to let the two studied permeants diffuse freely. Figures 6 and 8 show distinct changes in permeability based on the redox marker size and confirm that mass transport of the large

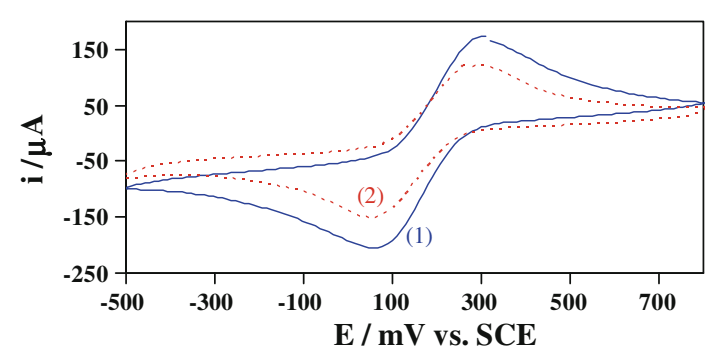

Fig. 7 Cyclic voltammograms (first cycles) of $10 \mathrm{mmol} \mathrm{L}^{-1}$ potassium ferricyanide recorded on bare (curve 1) and polyphenol filmcoated (curve 2) vitreous carbon electrodes at $25^{\circ} \mathrm{C}$ in $\mathrm{pH} 7$ sodium phosphate $\left(0.1 \mathrm{~mol} \mathrm{~L}^{-1}\right)$ buffer solution; scan rate: $500 \mathrm{mV} \mathrm{s}^{-1}$. The polyphenol film was prepared by anodic polarization at $1,200 \mathrm{mV}$ for $30 \mathrm{~min}$ in $10 \mathrm{mmol} \mathrm{L}^{-1}$ phenol aqueous solution containing $1 \mathrm{~mol} \mathrm{~L}^{-1} \mathrm{NaOH}$ at $25^{\circ} \mathrm{C}$

ferricyanide ion through the polymeric film was slower than that of the smaller phenate ion.

From these results it may be concluded that the apparent permeability of the polymeric film acquires significant values as soon as the potential allows oxygen evolution from 25 to $85{ }^{\circ} \mathrm{C}$. As the diffusion coefficient is lower in the film than in the solution, then $P(\%)$ should be smaller than $100 \%$. Values of $P \geq 100 \%$ indicate that the permeability is governed by the preferential partitioning of the probe into the polyphenol film due to stronger interactions (electrostatic, hydrophobic, etc.) in the film than in the solution [21]. Another explanation for values of phenate ion permeability higher than $100 \%$ (Figs. 6, 8) may be the low value of the peak phenol oxidation current measured during the first scan recorded on the bare vitreous carbon; this low value of the peak current is probably due to the fact that the polymeric layer formed at the beginning of the first scan at the bare electrode by direct electron transfer in the absence of oxygen evolution is compact, non-porous and non-conductive. 


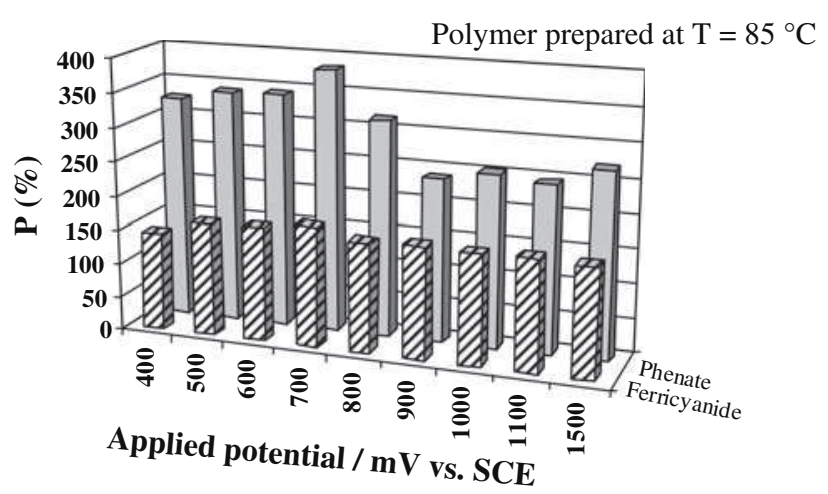

Fig. 8 Relationships between apparent permeability and applied potential. The polymeric film was prepared by anodic polarization at various applied potentials $\left(400-1,500 \mathrm{mV}\right.$ ) for $10 \mathrm{~min}$ in $1 \mathrm{~mol} \mathrm{~L}^{-1}$ $\mathrm{NaOH}$ aqueous solution containing $5 \mathrm{mmol} \mathrm{L}{ }^{-1}$ phenol at $85^{\circ} \mathrm{C}$. The permeability values $P(\%)$ of the polymeric film for ferricyanide and phenate ions were, respectively, calculated from cyclic voltammograms depicted in Figs. $4 \mathrm{~b}$ and $5 \mathrm{~b}$

\subsection{Oxidation of phenol in $1 \mathrm{~mol} \mathrm{~L}^{-1} \mathrm{H}_{2} \mathrm{SO}_{4}$ aqueous solution}

\subsubsection{Cyclic voltammetry}

In a previous work [17], we observed that the electrochemical response of $5 \mathrm{mmol} \mathrm{L}^{-1}$ phenol in $1 \mathrm{~mol} \mathrm{~L}^{-1}$ $\mathrm{H}_{2} \mathrm{SO}_{4}$ at $25{ }^{\circ} \mathrm{C}$ recorded on vitreous carbon at a scan rate of $100 \mathrm{mV} \mathrm{s}^{-1}$ was typical of an irreversible electrode reaction. The oxidation peak of phenol was observed at around $1,041 \mathrm{mV}$ in the potential region of water stability. The oxidation peak disappeared during continuous potential scanning right from the second cycle indicating that the electrode was deactivated [17].

\subsubsection{Evaluation of the apparent permeability of the polymeric film prepared under potentiostatic condition}

Polymeric films were electrodeposited under controlled polarization on vitreous carbon at various applied potentials for $10 \mathrm{~min}$ in $1 \mathrm{~mol} \mathrm{~L}{ }^{-1} \mathrm{H}_{2} \mathrm{SO}_{4}$ aqueous solution containing $1 \mathrm{mmol} \mathrm{L}{ }^{-1}$ of phenol at 25 or $85^{\circ} \mathrm{C}$. To assess the permeability for ferricyanide ion and phenol as defined by Eq. (1), the polymer-coated vitreous carbon was subjected to cycling (1) in $10 \mathrm{mM}$ potassium ferricyanide $+1 \mathrm{M} \mathrm{H}_{2} \mathrm{SO}_{4}$ at $25{ }^{\circ} \mathrm{C}$ and (2) in the same solution used for the film preparation. Cyclic voltammograms obtained at polymercoated and bare vitreous carbon electrodes are presented in Fig. 9 for ferricyanide ion and Fig. 10 for phenol molecule. The relationships between the apparent permeability of the polymeric films prepared at $25{ }^{\circ} \mathrm{C}$ in $1 \mathrm{~mol} \mathrm{~L}^{-1} \mathrm{H}_{2} \mathrm{SO}_{4}$ and the applied potential are shown in Fig. 11. These polymeric films were not permeable to ferricyanide ion whatever the applied potential between 1,300 and 2,300 mV. In contrast, the permeability for phenol molecules increased slowly as a function of the applied potential from 1,300 to $1,900 \mathrm{mV}$ situated at the onset of oxygen evolution (Fig. 2, curve d), then tended to stabilize. Overall, $P(\%)$ which remains lower than $100 \%$ shows that films so prepared exhibited some particle sieving.

Figure 12 shows the variation of the apparent permeability of the polymeric film prepared at $85^{\circ} \mathrm{C}$ in $1 \mathrm{~mol} \mathrm{~L}^{-1} \mathrm{H}_{2} \mathrm{SO}_{4}$ as a function of the applied potential. Below $1,300 \mathrm{mV}$ the polymeric film effectively excluded the phenol molecule; above $1,300 \mathrm{mV}$, at the onset of oxygen evolution (Fig. 2, curve c), the permeability for phenol increased rapidly with the applied potential up to $1,700 \mathrm{mV}$ then stabilized. However, the apparent permeability to ferricyanide ion remained nil up to $1,700 \mathrm{mV}$ then increased rapidly with the applied potential.

These results show that increasing the oxygen evolution occurring during electrodeposition of the polymeric film at $85{ }^{\circ} \mathrm{C}$ significantly increased its permeability for ferricyanide. However, the polymeric film prepared at $25{ }^{\circ} \mathrm{C}$ had no permeability whatever the potential at which it was prepared. In contrast, the concomitant oxygen evolution did play a positive role in increasing the permeability of the polymeric film prepared at 25 as $85^{\circ} \mathrm{C}$ to phenol. This may be interpreted by the fact that increasing the concomitant oxygen evolution increases the pore density in the polymeric film while increasing the temperature enlarges the pores size.

\subsection{Ability of electropolymerization to remove phenol from aqueous solutions}

In our previous studies we suggested that phenol could be removed from an aqueous solution by electropolymerization provided that the operating conditions continue to avoid anode fouling [15-18]. Thus, the resulting polymeric film formed at the electrode surface should have the highest permeability for phenol molecules in order to proceed by electropolymerization as long as a current is supplied to the electrode. The temperature and the applied potential constitute two key factors affecting the polymeric film permeability; they provide a basis for finding the best operating conditions that favor electropolymerization while avoiding electrode fouling. The apparent permeability was higher in basic than in acid medium whatever the applied potential and temperature used during the polymeric film preparation. For applied potentials situated at the onset of oxygen evolution, the polymeric film was more permeable for phenol when prepared at 85 than $25^{\circ} \mathrm{C}$. The optimal potential for the removal of phenol by electropolymerization at $85{ }^{\circ} \mathrm{C}$ was about $400-700 \mathrm{mV}$ in $\mathrm{NaOH} 1 \mathrm{~mol} \mathrm{~L}^{-1}$ and $1,700-2,100 \mathrm{mV}$ in $\mathrm{H}_{2} \mathrm{SO}_{4} 1 \mathrm{~mol} \mathrm{~L}^{-1}$. 
Fig. 9 Cyclic voltammograms (first cycles) recorded on bare and polyphenol film-coated vitreous carbon electrodes in $1 \mathrm{~mol} \mathrm{~L}^{-1} \mathrm{H}_{2} \mathrm{SO}_{4}$ aqueous solution containing

$10 \mathrm{mmol} \mathrm{L}^{-1} \mathrm{~K}_{3} \mathrm{Fe}(\mathrm{CN})_{6}$ at $25^{\circ} \mathrm{C}$. Scan rate: $500 \mathrm{mV} \mathrm{s}^{-1}$. The polyphenol films were prepared by anodic polarization at various applied potentials $(1,100-2,300 \mathrm{mV})$ for $10 \mathrm{~min}$ in $1 \mathrm{~mol} \mathrm{~L}^{-1} \mathrm{H}_{2} \mathrm{SO}_{4}$ aqueous solution containing $1 \mathrm{mmol} \mathrm{L}^{-1}$ phenol at $25^{\circ} \mathrm{C}$ (a) and $85^{\circ} \mathrm{C}$ (b)

Fig. 10 Cyclic voltammograms (first cycles) recorded on bare and polyphenol film-coated vitreous carbon electrodes in $1 \mathrm{~mol} \mathrm{~L}^{-1} \mathrm{H}_{2} \mathrm{SO}_{4}$ aqueous solution containing $1 \mathrm{mmol} \mathrm{L}^{-1}$ phenol at $25^{\circ} \mathrm{C}$ (a) and $85^{\circ} \mathrm{C}$ (b). Scan rate: $100 \mathrm{mV} \mathrm{s}^{-1}$. The polyphenol films were prepared by anodic polarization at various applied potentials $(1,100-2,300 \mathrm{mV})$ for $10 \mathrm{~min}$ in $1 \mathrm{~mol} \mathrm{~L}^{-1} \mathrm{H}_{2} \mathrm{SO}_{4}$ aqueous solution containing $1 \mathrm{mmol} \mathrm{L}^{-1}$ phenol at $25^{\circ} \mathrm{C}$ (a) and $85^{\circ} \mathrm{C}$ (b)
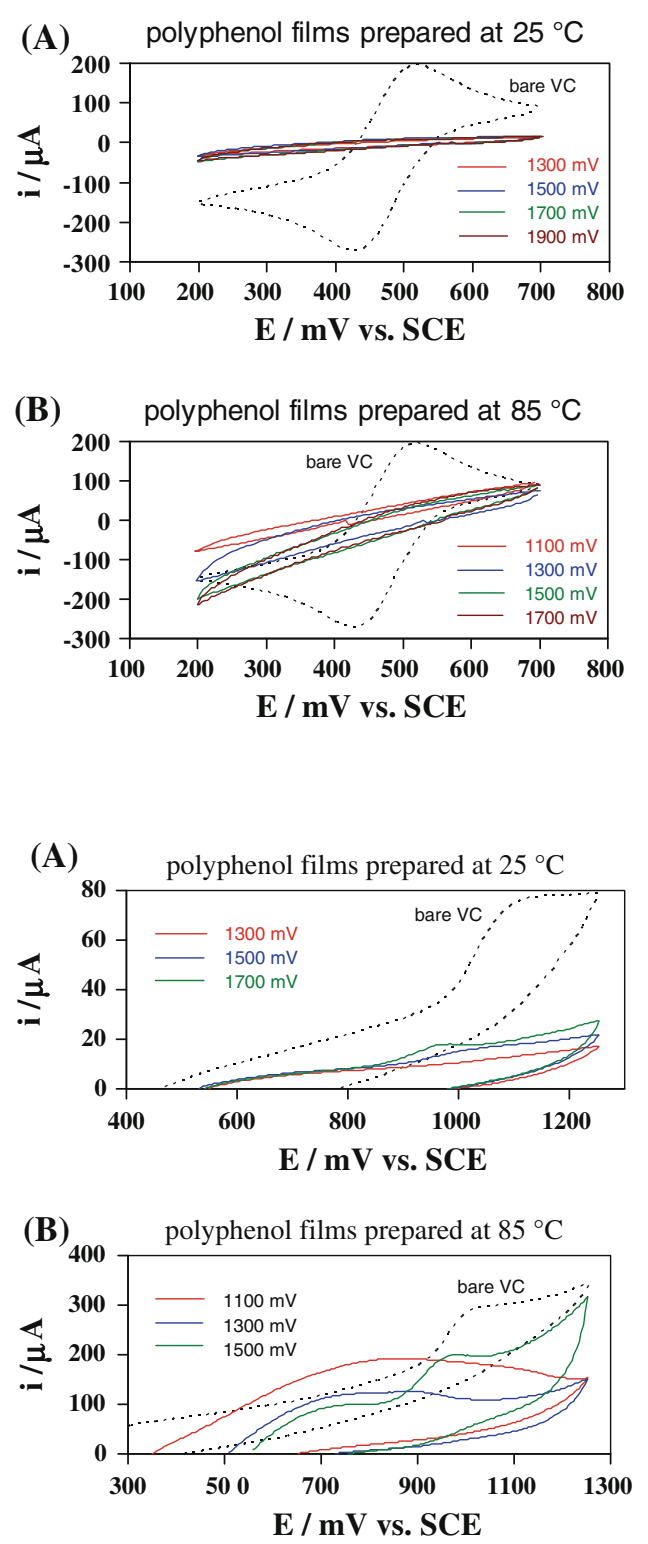
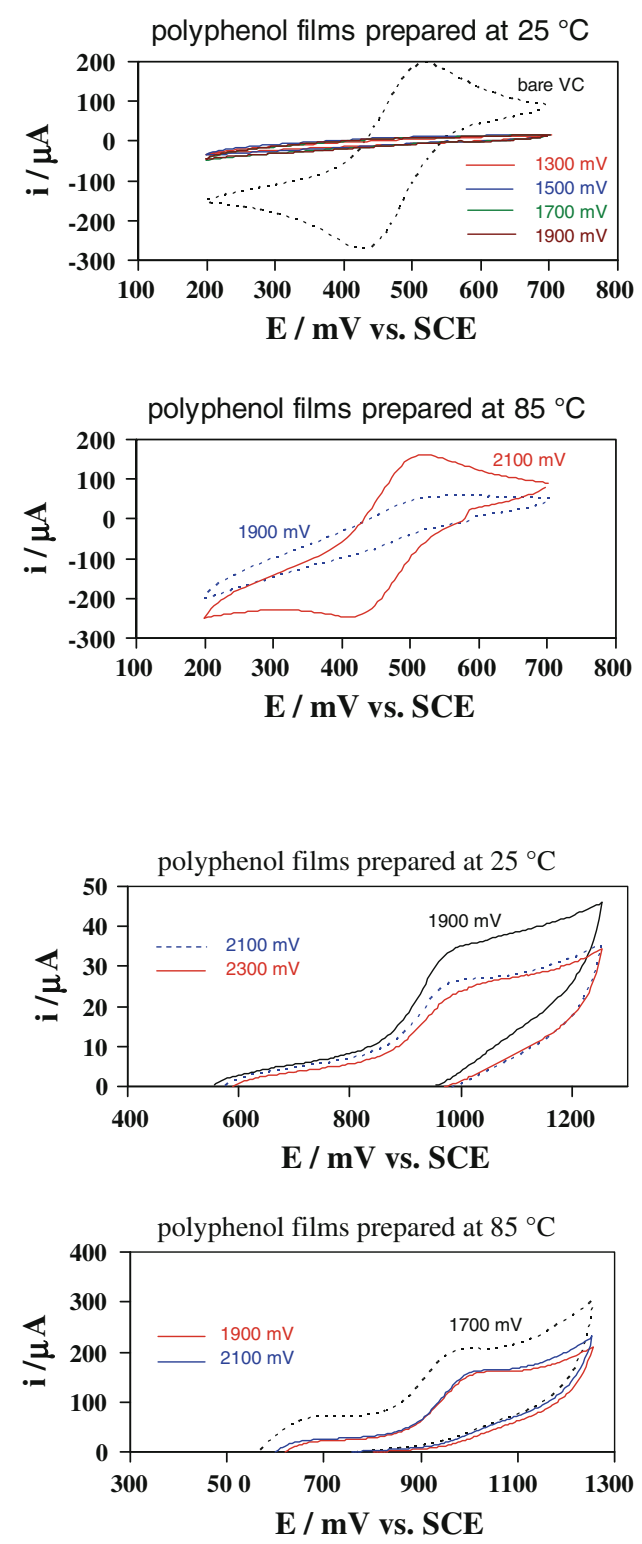

\section{Conclusions}

We have shown that the apparent permeability of the polyphenol film varied with the experimental parameters such as temperature and the potential applied for its electrosynthesis in acidic or alkaline aqueous solution. The highest permeability versus phenol and ferricyanide ion was obtained when the polymeric film was prepared at high temperature and in the presence of a concomitant oxygen evolution in both acidic and alkaline solutions. In contrast, polyphenol films prepared by direct electron transfer in the potential region of water stability were permeable to the small water molecule while effectively excluding, even when prepared at high temperature, the much larger phenol molecule and ferricyanide ion. These results are interpreted in terms of a mixed-transport mechanism involving both pore and membrane diffusion of the probes through the polyphenol film. The pore mechanism occurs predominately in the polyphenol film prepared at high temperature and in the presence of a concomitant oxygen evolution; this $\mathrm{O}_{2}$ gas evolution plays a crucial role in enhancing the permeability by increasing the density of pores within the film while it is assumed that high temperatures make the pores greater in size. However, membrane diffusion is the primary transport mode in polyphenol films prepared at low temperatures and in the absence of oxygen evolution. As expected, membrane diffusion, being sensitive to the molecular size of the probes, allows the passage of small water molecules and excludes large phenol molecules and ferricyanide ions. 


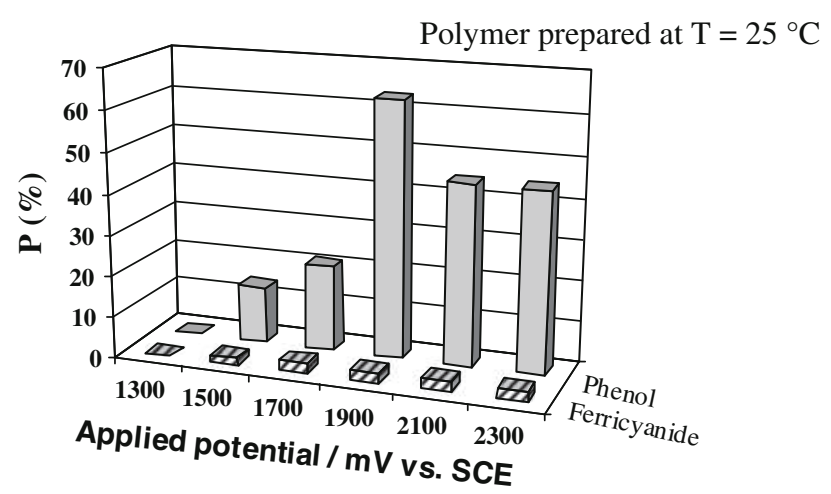

Fig. 11 Relationships between apparent permeability and applied potential. The polymeric film was prepared by anodic polarization at various applied potentials $(1,300-2,300 \mathrm{mV})$ for $10 \mathrm{~min}$ in $1 \mathrm{~mol} \mathrm{~L}^{-1}$ $\mathrm{H}_{2} \mathrm{SO}_{4}$ aqueous solution containing $1 \mathrm{mmol} \mathrm{L}{ }^{-1}$ phenol at $25^{\circ} \mathrm{C}$. The permeability values $P(\%)$ of the polymeric film for ferricyanide and phenate ions were, respectively, calculated from cyclic voltammograms depicted in Figs. 9a and 10a

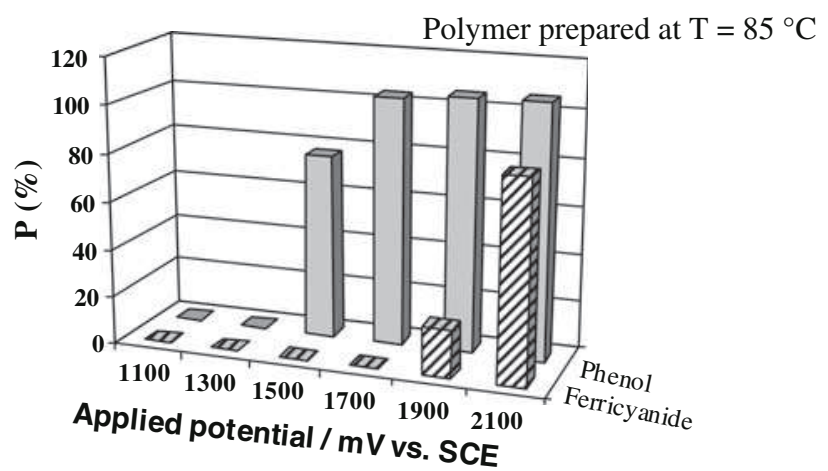

Fig. 12 Relationships between the apparent permeability and the applied potential. The polymeric film was prepared by anodic polarization at various applied potentials $(1,100-2,100 \mathrm{mV})$ for $10 \mathrm{~min}$ in $1 \mathrm{~mol} \mathrm{~L}^{-1} \quad \mathrm{H}_{2} \mathrm{SO}_{4}$ aqueous solution containing $1 \mathrm{mmol} \mathrm{L}{ }^{-1}$ phenol at $85^{\circ} \mathrm{C}$. The permeability values $P(\%)$ of the polymeric film for ferricyanide and phenate ions were, respectively, calculated from cyclic voltammograms depicted in Figs. 9b and 10b

\section{References}

1. Belhadj Tahar N, Savall A (1998) Mechanistic aspects of phenol electrochemical degradation by oxidation on a $\mathrm{Ta} / \mathrm{PbO}_{2}$ anode. J Electrochem Soc 145:3427-3434

2. Iniesta J, Gonzalez-Garcia J, Exposito E, Montiel V, Aldaz A (2001) Influence of chloride ion on electrochemical degradation of phenol in alkaline medium using bismuth doped and pure $\mathrm{PbO}_{2}$ anodes. Water Res 35:3291-3300

3. Panizza M, Michaud PA, Cerisola G, Comninellis Ch (2001) Anodic oxidation of 2-naphthol at boron-doped diamond electrodes. J Electroanal Chem 507:206-214

4. Rodrigo MA, Michaud PA, Duo I, Panizza M, Cerisola G, Comninellis Ch (2001) Oxidation of 4-chlorophenol at borondoped diamond electrode for wastewater treatment. J Electrochem Soc 148:D60-D64
5. Feng YJ, Li XY (2003) Electro-catalytic oxidation of phenol on several metal-oxide electrodes in aqueous solution. Water Res 37:2399-2407

6. Li XY, Cui YH, Feng YJ, Xie ZM, Gu JD (2005) Reaction pathways and mechanisms of the electrochemical degradation of phenol on different electrodes. Water Res 39:1972-1981

7. Oyama N, Ohsaka T, Ohnuki Y, Susuki T (1987) Anodic oxidation of 2,6-dimethylphenol in various electrolytic solutions. J Electrochem Soc 134:3068-3078

8. Bartlett PN, Cooper JM (1993) A review of the immobilization of enzymes in electropolymerized films. J Electroanal Chem $362: 1-12$

9. Gattrell M, MacDougall B (1999) The anodic electrochemistry of pentachlorophenol. J Electrochem Soc 146:3335-3348

10. Kuramitz H, Nakata Y, Kawasaki M, Tanaka S (2001) Electrochemical oxidation of bisphenol A. Application to the removal of bisphenol A using a carbon fiber electrode. Chemosphere 45: $37-43$

11. Kuramitz H, Saitoh J, Hattori T, Tanaka S (2002) Electrochemical removal of $p$-nonylphenol from dilute solutions using a carbon fiber anode. Water Res 36:3323-3329

12. Kuramitz H, Matsushita M, Tanaka S (2004) Electrochemical removal of bisphenol A based on the anodic polymerization using a column type carbon fiber electrode. Water Res 38:2331-2338

13. Sripriya R, Chandrasekaran M, Subramanian K, Asokan K, Noel M (2007) Electrochemical destruction of $p$-chlorophenol and $p$ nitrophenol: influence of surfactants and anode materials. Chemosphere 69:254-261

14. Zhang Y, Li Q, Cui H, Zhai J (2010) Removal of phenols from the aqueous solutions based on their electrochemical polymerization on the polyaniline electrode. Electrochim Acta 55: 7219-7224

15. Belhadj Tahar N, Abdelhedi R, Savall A (2009) Electrochemical polymerization of phenol in aqueous solution on $\mathrm{Ta} / \mathrm{PbO}_{2}$ anode. J Appl Electrochem 39:663-669

16. Belhadj Tahar N, Savall A (2009) Electrochemical removal of phenol in alkaline solution. Contribution of the anodic polymerization on different electrode materials. Electrochim Acta 54: 4809-4816

17. Belhadj Tahar N, Savall A (2011) Electropolymerization of phenol on a vitreous carbon electrode in acidic aqueous solution at different temperatures. J Appl Electrochem 41:983-989

18. Belhadj Tahar N, Savall A (2009) Electropolymerization of phenol on a vitreous carbon electrode in alkaline aqueous solution at different temperatures. Electrochim Acta 55:465-469

19. Belhadj Tahar N, Savall A (2012) Effect of electropolymerisation conditions on the permeability of polyphenol films deposited on a vitreous carbon electrode. Electrochim Acta 82:427-433

20. Rothwell SA, McMahon CP, O'Neill RD (2010) Effects of polymerization potential on the permselectivity of $\operatorname{poly}(o$-phenylenediamine) coatings deposited on Pt-Ir electrodes for biosensor applications. Electrochim Acta 55:1051-1060

21. Cruz J, Kawasaki M, Gorski W (2000) Electrode coatings based on chitosan scaffolds. Anal Chem 72:680-686

22. Martinez-Huitle CA, Carlesi Jara C, Cerro-Lopez M, Quiroz MA (2009) Chitosan-modified glassy carbon electrodes: electrochemical behaviour as a function of the preparation method and pH. Can J Anal Sci Spectrosc 54:53-62

23. Mengoli G, Musiani MM (1987) An Overview of phenol electropolymerization for metal protection. J Electrochem Soc 134: $643 \mathrm{C}-652 \mathrm{C}$

24. Wang J, Lin MS (1988) In situ electrochemical renewal of glassy carbon electrodes. Anal Chem 60:499-502

25. Wang J, Jiang M, Lu F (1998) Electrochemical quartz crystal microbalance investigation of surface fouling due to phenol oxidation. J Electroanal Chem 444:127-132 
26. Kennedy BM, Cunnane VJ (2008) The degradation of electrochemically polymerised poly(3-aminophenol) films in sodium hydroxide solutions for the production of microelectrode ensembles. Electrochim Acta 53:3620-3625

27. Kennedy BM, Cunnane VJ (2008) The degradation of pinhole free poly(1,3-dihydroxybenzene) films in sodium hydroxide for the production of microelectrode ensembles. J Electroanal Chem 615:197-204
28. Pressprich KA, Maybury SG, Thomas RE, Linton RW, Irene EA, Murray RW (1989) Molecular sieving by electropolymerized porphyrin films only a few monolayers thick. J Phys Chem 93:5568-5574

29. McCarley RL, Irene EA, Murray RW (1991) Permeant molecular sieving with electrochemically prepared 6-nm films of poly (phenylene oxide). J Phys Chem 95:2492-2498 